Pakistan Journal of Education

Vol.37, No.2, 2020, 61-78

\title{
Effectiveness of Educational videos and Games for the Concept Clarity and Understanding of Social Studies Subject: An Intervention Study
}

\author{
Farhana Khurshid* \\ Maria Bibi $^{* *}$
}

\begin{abstract}
Information and Communication Technology (ICT) is considered as a key requirement for learners because it augments their learning. This study investigated the effectiveness of utilising educational videos and games into teaching for better understanding and concept clarity of students in the subject of Social Studies. This experimental study was conducted in two government secondary schools, for four weeks on a sample size of fifty-eight students of $8^{\text {th }}$ class. Different topics from Social Studies subject were taught to the sample with the help of educational videos and games. A test was constructed to assess students' concept understanding of the topics taught during the experiment, which was utilised as pre- and post-test for the study. The difference between the social studies concept understanding of control and experimental group students was calculated through t-tests. The significant values of $\mathrm{t}-$ tests $(\mathrm{p}=0.00)$ and effect size $(\mathrm{r}=0.96)$ indicated that teaching through educational videos and games helped students in better way for their clarity of abstract and complex concepts of Social Studies subject. In the focus group discussion, students mentioned that teaching with educational videos and games helped them in understanding the difficult concepts of Social Studies and developed their interest in the subject.
\end{abstract}

Keywords: information and communication technology (ICT), educational videos and games, social studies subject, teaching, learning.

Assistant Professor, Department of Education, FJWU,

Email: f.khurshid@ fjwu.edu.pk

** Ph.D Scholar, Department of Education, FJWU, Email: mariabibi89@gmail.com 


\section{Introduction}

We are living in the $21^{\text {st }}$ century; a technological advancement era. Information and Communication Technology (ICT) is used all around the world in almost all fields of life, and in education as well. In majority of educational institutions around the world, the integration and use of information and communications technologies (ICTs) have become a necessary element for teaching and for the learning as well (Juang, Liu \& Chan, 2008). The basic purpose for the use of modern technology in education is to enhance students' learning and improve their academic achievement (Acikalin \& Erdinç, 2005). There are different abstract concepts in the subject of social studies (e.g Cyclones and Desertification), that are difficult for students to understand and learn. Similarly, teachers also find it difficult to teach these concepts through the lecture method only. Keeping in view the difficulty of students in learning abstract concepts of social studies subject through traditional teaching methods, one understands the usefulness of ICTs in this regard. The use and application of different ICT tools, such as educational videos and games, into teaching, work best in enhancing learning of students (Sedaghat, Mintz, \& Wright, 2011). Therefore, this study was planned with the objectives:

- To try out the use of educational videos and games in teaching of social studies subject at secondary level.

- To help students learn and comprehend the abstract and complex concepts of the social studies subject, with the help of educational videos and games.

\section{Literature Review}

\section{Importance of Information and Communication Technology (ICT)}

It is the age of technology, information and Communication Technologies (ICTs) are used as a helping tool in teaching learning process. The quality of the teaching can be improved with the integration of ICTs in teaching and learning. It helps teachers to make their jobs easy and also aid students to learn successfully. The $21^{\text {st }}$ Century demands to change the role of teacher with the integration of ICTs into teaching and learning (Goktas, Yildirim, \& Yildirim, 2009). ICT is not merely suitable for learners just in their classroom, it is helpful for their future practical life as well (Wheeler, 2001). The importance of integration of ICTs at secondary schools cannot be ignored. Everyone needs to practice ICT proficiently for the improvement in overall academic performance (Adomi \& Anie, 2006). Research indicated that 
ICT influences the teaching and learning process in different ways e.g. as a helping tool for the collection of different types of information, consolidating the learning programs, forming educational courses and also for the purpose of communication with each other etc. (Collis, 1999; Collis \& Wende, 2002).

Teaching through educational videos and games assist students in their learning. Various research studies have found that the use of ICTs in educational institutions improve learners' comprehension and encourage them to involve actively into their studies as compared to other conventional teaching methods (Safder, 2013; Gaudence, Too, \& Nabwire, 2013). Different researchers and educationists use this tool positively in the teaching-learning process, so that learners' involvement and participation in the learning sessions can make certain (Yang, Huang, Tsai, Chung, \& Wu, 2009).

\section{Teaching and Learning with Educational Videos and Games}

Teaching with educational videos and games provides students a virtual environment. The main features include; challenges, instructions, aims, response, collaboration and story (Prensky, 2001). ICT tools could be effectively utilised for the quality enhancement of education in different disciplines for the achievements of the learning outcomes. Prensky (2001), highlighted the potential of digital game based learning as, "motivation can finally be found for learning the subjects and content that are the most difficult to teach or train, either because they are extremely dull and dry or extremely complicated to learn" (p.17)

\section{Teaching of Social Studies}

The importance of the Social Studies subject cannot be denied. In this subject, students get knowledge about social life and social issues. The knowledge about historical events is also the part of this subject. Social Studies subject is taught to students as part of curriculum in our public schools. There was different research studies conducted on the subject of social studies describing its significance for the students (Acikalin \& Erdinç, 2005; Gulbahar \& Guven 2008; Ni, 2012). Frye, Trathen and Koppenhaven (2010) highlighted the significance of teaching this subject. The social studies teachers are responsible to teach students effectively, the values, skills and knowledge that is mandatory to become a good citizen. In the social studies subject, the teachers make students able to gain, understand, interpret, and communicate the information with each other. 
There are different concepts in social studies subject that are difficult for students to understand via the lecture method only. Teaching and learning through educational videos and games helped to overcome this problem. Educational videos and games are helpful for teachers, as they can easily teach the abstract concepts, and students can learn them easily. Video game applications in the teaching-learning environment is based on the educators' enthusiasm to implement technology into their classrooms (Jaipal \& Figg, 2009). Actual games that enhance learning are recognized through direct response, clear objectives, and tasks that are coordinated to player's abilities and learning stages (Kili, 2005). Educational videos are the influential tools that can be used as a medium for students to better learn and understand various curriculum areas (Greenberg \& Zanetis, 2012). Here the quote of LeFevre (2004) is important "Video can become a part of a curriculum for learning if it is designed to be used in intentional ways towards intentional learning goals" (p. 235).

A research was conducted by Gaudence, Too, and Nabwire (2013) in Kenya about the use of video into teaching to increase students' learning of geography subject. It was an experimental study, pre- \& post -tests were taken from control and experimental groups. The results show that experimental groups learn well as compared to control group. Hsu, Hwang, Chang, and Chang (2013) conducted a study wherein they used educational videos using images, listening, understanding and terminology achievement of English language learning. This study was experimental and consisted of one month experimentation. They assessed learners' achievement on weekly basis. Results show that English language learning of experimental group was better as compared to control group.

\section{Rationale of the Study}

In social studies subject, there are different topics based on the abstract concepts, e.g. weather change, cyclone, process of rain fall, and desertification etc, that cause difficulty for students to understand when taught conventionally through lecture method. There were different specific objectives of teaching of the social studies subject that were stated in the book, but not achieved because of teaching through the lecture method only. Conventional methods of teaching i.e. lecture method, did not allow teaching these types of concepts effectively. Keeping this in view, the difficulty of students in learning these abstract concepts of social studies subject through traditional method, one understands the usefulness of ICTs in this regard. Therefore, this study 
aimed at exploring the effectiveness of educational videos and games in students' understanding of abstract and complex concepts of social studies subject. Moreover, another purpose of the study was to create awareness among teachers and students about the appropriate use of educational videos and games for teaching, resultantly, for better understanding and concept clarity of students.

\section{Theoretical Underpinning of the Study}

Activity theory provided theoretical background for this study. The arguments of activity theory are (Vygotsky, 1978) that human activity includes a comprehensive system of human actions, including purposeful and meaningful activities, tacit and inexplicit forms of conducting activities, and physical and theoretical instruments are utilised for accomplishing these activities.

Engeström in 1987, developed a model of an activity system, where all its components are being portrayed (Figure 1). Engeström argued that applying activity theory to a study can attract the attention of the researcher to important factors to consider when evaluating teaching and learning activities (Mwanza \& Engeström 2005, p.457). Activity theory model provided a powerful conceptual framework for numerous studies about the use of ICT in educational settings (Yocam, Wilmore et al. 1994; Tolmie and Boyle 2000; Lim 2001; Lim and Hang 2003).

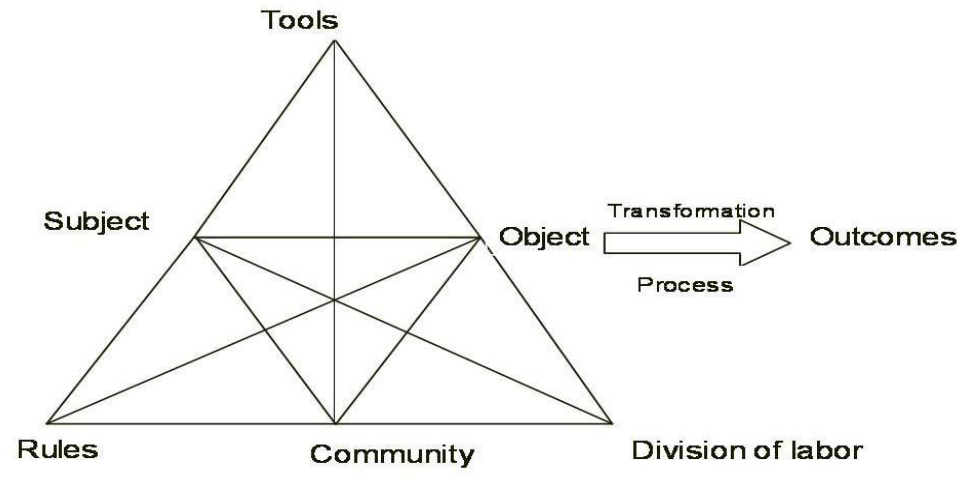

Figure 1: Activity system, based on model of Engeström (1987)

The model of activity triangle presents how different components of an activity are related and worked together in a system where the particular activity is carried out. It had six main components as shown in Figure.1; Tools, rules, object, subject, community, and division of labour. In this study the educational videos and games were used as tool. 
The teachers (subject teachers and class teachers) and students of both schools are considered here as subject. Teaching through educational videos and games, specially in Social Studies subject is very interesting and innovative. So, in current study teaching through videos and games for the social studies subject is considered as the object. The rules for the system included the curriculum requirements, availability of computers, class time, appropriate behavior of the students etc. Community referred to both schools (School A, School B), and the $8^{\text {th }}$ class students of these schools. The division of labour distinguish the functions of members of community i.e. role of teacher, role of the students. Here students were assigned work in individual and group activities, their role in group work was the focus.

\section{Research Question}

- What is the impact of teaching through educational videos and games on students' learning and concept clarity in the social studies subject at secondary school level?

- What views the students have towards the use of videos and games for their learning and concept clarity of social studies subject at secondary level?

\section{Methodology}

This study was mixed-method in nature, combining the quantitative and qualitative methods. First the experiment was conducted wherein, pre-test, post-test control group design was applied. After that, four focus group discussions were conducted with the students who were the part of experimental group.

\section{Sample}

Two schools were selected from the locality of Islamabad city. The administration allowed to conduct experiments with $8^{\text {th }}$ class students. For this purpose, fifty-eight students of $8^{\text {th }}$ class, i.e. 29 students from each school, were taken as sample for this research. Among them two groups, control and experimental, were created by applying random assignment. Experimental and control groups comprised of 15 and 14 students each, respectively. 


\section{Experiment}

The experiment was conducted simultaneously in two schools for a duration of four weeks. For the experiment, first of all, the topics of social studies were selected in consultation with the subject teachers of both schools. Teachers suggested the topics which they considered were complex and more abstract in nature, and students felt difficulty in understanding them. These topics include the concepts of cyclone and desertification etc. The selected topics were taught to the experimental groups utilising educational videos and games, while the control groups had been taught traditionally i.e. through lecture method only. The experiment was conducted in two schools to check whether the context effects on students' results, or not.

First a test was constructed on the selected topics, in consultation with the social studies subject teachers. There were six main sections of the test with forty-six items. For the construction of test, Bloom's Taxonomy's cognitive domain was followed. The test measured students" "skills of knowledge, comprehension, application, analysis, synthesis and evaluation" (Bloom, 1956, p.200). The test was validated from social studies subject teachers. For the reliability analysis, this test was administered to thirty (30), $8^{\text {th }}$ class students, which were not included in the sample of this research. The value of Chronbach's Alpha coefficient, 0.75 , indicated that the test was reliable to use in this research. This test was utilised as pre- and post-test, to assess students' level of understanding and concept clarity of the topics from Social Studies subject, before and after the experiment.

After random assignment, the students of $8^{\text {th }}$ class were divided in two halves, control and experimental groups, then all students of these groups were pre-tested. Educational videos and games were utilised to teach the experimental groups of both schools, the control groups students were taught through lecture method without any intervention. This intervention lasted for four weeks. Both control and experimental group students were post-tested after the experiment was completed. The data obtained from pre-test and post-test was quantitative i.e. students' scores on these tests.

At the end of experiment, the students of experimental groups were invited to participate in focus group discussions. The purpose was to get the views of students about their experience of learning social studies subject with educational videos and games. 


\section{Data Analysis}

The t-tests (independent and paired sample) were calculated to find out whether the pre- and post-tests' mean scores of control groups were significantly different from the pre- and post-tests' mean scores of experimental groups. Results of paired sample t-test for the experimental groups determines whether the post-test mean scores were significantly different from the pre-test mean scores. The results of independent sample t-test determines whether the post-test mean scores of experimental groups were significantly different from the post-test mean scores of control groups.

Results presented in Table 1 compares experimental group's preand post-test scores. In order to find the significant difference between the experimental group's pre- and post-test scores of school 1(one), a paired sample t-test was calculated. The results of t-test show that the experimental group's post test scores $(\mathrm{M}=37.25, \mathrm{SD}=7.8)$ were higher than those of the pre-test $(\mathrm{M}=14.75, \mathrm{SD}=4.4)$ and the difference was statistically significant $(\mathrm{p}=0.00)$. This indicated that learning with educational videos and games enhanced students' understanding of social studies subject.

Table 1

Results of paired sample t-test for experimental group's pre- and posttest scores of school 1 (one). $(n=14)$

\begin{tabular}{lrrrrr}
\hline $\begin{array}{l}\text { Experimental } \\
\text { Group }\end{array}$ & Mean & SD & $t$-value & $d f$ & $p$ \\
\hline Pre-test score & 14.75 & 4.4 & & & \\
Post-test & 37.25 & 7.8 & -14.17 & 13 & .000 \\
score $)$ & & & & & \\
\hline
\end{tabular}

Table 2 shows a comparison of the experimental and control group's post-test scores of school 1 (one). The independent sample t-test was calculated to determine the significant difference between the experimental and control group's post-test scores of school 1 (one). The results of the t-test showed the statistically significant difference $(p=0.00)$ between the experimental group's post-test scores $(M=37.25$, $\mathrm{SD}=7.8)$ and the control group's post-test scores $(\mathrm{M}=16.14, \mathrm{SD}=3.5)$. This indicated that the understanding of the concepts of social studies subject, was better for the experimental group than the control group students. 
Table 2

Results of Independent sample t-test for the control and experimental groups' post-test scores at school 1 (one). $(n=29)$

\begin{tabular}{lccccc}
\hline Group & Mean & SD & $t$-value & $d f$ & $p$ \\
\hline $\begin{array}{l}\text { Experimental } \\
\text { Group(post- } \\
\text { test score) }\end{array}$ & 37.25 & 7.8 & 9.180 & & \\
$\begin{array}{l}\text { Control Group } \\
\text { (post-test } \\
\text { score) }\end{array}$ & 16.14 & 3.5 & 9.180 & 26 & .000 \\
\hline
\end{tabular}

Results presented in Table 3 compares experimental group's preand post-test scores at school 2 (two). In order to find the significant difference between the experimental group's pre- and post-test scores of school 2 (two), a paired sample t-test was calculated. The results of t-test show that the experimental group's post test scores $(\mathrm{M}=37.80, \mathrm{SD}=6.4)$ were higher than those of the pre-test $(\mathrm{M}=13.13, \mathrm{SD}=3.4)$ and the difference is statistically significant $(\mathrm{p}=0.00)$. This indicated that learning with educational videos and games enhanced students' understanding of social studies subject at school 2 as well.

Table 3

Results of paired sample t-test for the pre- and post-test scores of experimental group of school 2 (two). $(n=15)$

\begin{tabular}{lccccc}
$\begin{array}{l}\text { Experimental } \\
\text { Group }\end{array}$ & Mean & SD & $t$-value & $d f$ & $p$ \\
\hline $\begin{array}{l}\text { Pre-test } \\
\text { score }\end{array}$ & 13.13 & 3.4 & & & \\
$\begin{array}{l}\text { Post-test } \\
\text { score }\end{array}$ & 37.80 & 6.4 & -14.65 & 14 & .000 \\
\hline
\end{tabular}

Table 4 shows a comparison of the experimental and control group's post-test scores at school 2 (two). The independent sample t-test was calculated to determine the significant difference between the experimental and control group's post-test scores of school two. The results of the t-test showed the statistically significant difference $(p=0.00)$ between the experimental group's post-test scores $(M=37.80$, $\mathrm{SD}=6.4)$ and the control group's post-test scores $(\mathrm{M}=13.06, \mathrm{SD}=2.3)$. This indicated that as compared to the control group, the experimental group's students learn better the social studies subject after the experiment. 
Table 4

Results of Independent sample t-tests for the post-test scores of experimental group and control group of school 2(two) $(n=15)$

\begin{tabular}{lccccc}
\hline Group & Mean & SD & $t$-value & $d f$ & $p$ \\
\hline $\begin{array}{l}\text { Experimental } \\
\begin{array}{l}\text { Group(post-test } \\
\text { score) }\end{array}\end{array}$ & 37.80 & 6.4 & 13.89 & & \\
$\begin{array}{l}\text { Control } \\
\begin{array}{l}\text { Group(post-test } \\
\text { score) }\end{array}\end{array}$ & 13.06 & 2.3 & 13.89 & 28 & .000 \\
\hline
\end{tabular}

As mentioned earlier, the experiment was conducted in two schools, and it was considered important to check whether the experimental group students of both schools were different in their understanding of social studies concepts taught with educational videos and games, or not. This was checked through the independent sample ttest, calculated for the experimental group's mean scores of their posttests. The value of $\mathrm{p}=0.375$, indicated that there was no significant difference between the understanding of experimental groups students of both schools. These results are presented in table 5, below.

Table 5

Results of Independent Sample t-test for the post-test scores of experimental groups of both schools. ( $n=14$ and 15)

\begin{tabular}{lcccccc}
\hline Group & Mean & $\mathrm{N}$ & $\mathrm{SD}$ & $t$-value & $d f$ & Significant $\mathrm{p}$ \\
\hline $\begin{array}{l}\text { Experimental } \\
\text { Group (post- } \\
\text { test score)S1 }\end{array}$ & 37.25 & 14 & 7.8 & -.207 & & \\
$\begin{array}{l}\text { Experimental } \\
\text { Group (post- }\end{array}$ & 37.80 & 15 & 6.4 & -.205 & & .375 \\
$\begin{array}{l}\text { test } \\
\text { score)S2 }\end{array}$ & & & & & & \\
\hline
\end{tabular}

\section{Effect size}

The effect size is an unbiased and consistent measure to know the magnitude of the variance in two groups. It is used to quantify the magnitude of an effect (Field, 2009; Cohen, Manion \& Morrison, 2011). Pearson's correlation coefficient $\boldsymbol{r}$ was calculated to find out the magnitude of the variance. This decision was taken on the basis of the assumptions that it is generally understandable and regularly used by paired quantifiable data, it is specifically used to measure the power of 
the connection and association in two variables, it is controlled to remain between 0 (no effect) to 1 (perfect effect) and changing $t$-values to $r$ values is comparatively direct.

Field (2009) and Cohen $(1988,1992)$ recommended the standards for measuring whether an effect is large or small must remain as follows: $r=0.50$ (large effect), $r=0.30$ (medium effect), $r=0.10$ (small effect)

Table 6 presents the results of the effect sizes calculated for school $1 \& 2$ using the results of the paired sample t-statistics presented in tables 2 and 4 above. The paired sample t-test calculated for the experimental group's pre- and post-test scores of both schools, were significant $(\mathrm{p}=0.00)$, and the value of $\mathrm{r}=0.96$, signifies a large effect. This indicated that teaching through educational videos and games had a large effect on students' learning of different concepts of social studies subject.

Table 6

Effect size (Magnitude of difference)

\begin{tabular}{llll}
\hline Schools & $t$-value & $p$-value & Effect Size \\
\hline School 1 & -14.17 & 0.00 & 0.96 (Large) \\
School 2 & -14.65 & 0.00 & 0.96 (Large) \\
\hline
\end{tabular}

\section{Qualitative Data Analysis}

The second research question entails the students' views about their experience of learning different concepts of Social Studies subject with educational videos and games. For this purpose, the experimental groups' students were invited for focus group discussions, which were audio recorded with their consent. Then these audio recordings were fully transcribed and analyzed thematically, in the light of 'Activity theory'. The six components of 'Activity theory' (as described in detail above) provided the main themes for the analysis of focus group discussion data.

Students discussed their experiences regarding learning through videos and games. They said that learning with educational videos and games helped them in improving their learning and they were able to understand various abstract concepts of Social Studies subject easily. It enabled them to clarify their confusion about different topics of social studies, which they always found difficult otherwise through lecture method.

For example student A said, "This is a very useful experience for me. I learned more about cyclones and land sliding with the help of videos and games." 
For students, it was a very attractive tool for learning. The eagerness and excitement of the students, in the Social Studies classes proved their interest in this new teaching and learning method. One student expressed,

"The social studies subject become very attractive and interesting through videos and games. Now, I like this subject very much".

Hence, with the incorporation of videos and games into teaching and learning, students not only learned theoretically, but the applied side of the concepts as well.

For example the concepts of 'cyclones' and 'desertification', students said that after watching the video, they understood what a cyclone look like and how it happened.

Students were more interested in searching the information on internet, related to the social studies subject topics, and they learned better at their own pace. Students said that now all topics they learned during this experiment, seemed very interesting to them. While, in the past, they considered Social Studies as a dull and bore subject, when taught verbally through lecture method only. Educational videos and games helped to overcome the boredom in Social Studies class.

The classroom turned into an interactive and attractive learning platform. The active participation of the learners in group activities increased their confidence level too. It appeal students to adopt modern technology due to its benefits for their leaning. They actively participated in different lesson activities in the classroom. Due to this experiment, the students learnt to collaborate with each other during the group work, thus a sense of team work was there.

As students found it interesting learning with educational videos and games, they suggested that ICT must be introduced not only for the teaching of Social Studies subject, but it must be a permanent part of all other subjects e.g. Science and Math etc.

\section{Discussion}

This research was aimed at finding out the effectiveness of educational videos and games for students' understanding and learning of social studies subject at secondary school level. The experimental and control groups were taken to find out the difference between learning of social studies subject with educational videos and games compared to traditional lecture method. These groups were compared on the scores of pre- and post-tests. The results of paired sample t-test $(\mathrm{p}=0.00)$ (Table 2) showed that the difference was significant between the experimental groups' pre- and post-test scores of both schools. On the other hand, 
experimental and control groups of both schools were compared on their scores of post-tests, wherein, the results of Independent sample t-test $(\mathrm{p}=0.00)$ (Table 3) showed that the difference was significant. It appeared from these results that the students of experimental groups learned better as compared to control groups of both schools. This indicated that educational videos and games were very useful for the concept clarity and better understanding of students, especially for the abstract and complex concepts of Social Studies subject. The results of effect size $(\mathrm{r}=0.96)$ showed that teaching with educational videos and games had a large effect on students leaning of social studies subject. The purpose of selection of two different schools for the experiment was to check whether the use of educational videos and games effected similarly, the learning of students in either educational institutions or there was any difference. The difference was statistically not significant $(\mathrm{p}=0.375)$ (Table 6), which indicated that context has no effect on students learning with educational videos and games.

These findings are akin to previous research (Maguth et al., 2015; Gaudence, Too, \& Nabwire, 2013), wherein, they used educational video games in the teaching of social studies subject. Results indicated that the use of educational video games in the classroom had positive effects on students learning and concept clarity as compared to traditional methods of teaching.

These findings were backed by the qualitative data, wherein, during the focus group discussions, students said that they were interested to learn through educational videos and games because it was new and innovative mode of learning for them. These videos and games facilitated them in learning and also provided assistance to learn new information through innovative strategies. Students found these educational videos and games as a source for the enhancement of their subject knowledge by providing them with adequate information about the difficult topics. Consequently, they developed interest towards their studies. There were different abstract concepts in the Social Studies subject that were well understood with the help of these educational video and games. Students were excited about that their bore and dull social studies classroom became a cheerful place filled with novel games and activities relevant to their studies. The active participation of the learners in group activities increased their confidence level, in this way slow and shy students were changed into active and enthusiastic learners. Adopting this novel learning technique students used internet during studies and developed themselves as independent and self-reliant learners. They themselves searched more material from internet related to their studies. Furthermore, they explained that educational videos and 
games were essential tools for enhancing their creativity to think about the different aspects of the concepts presented to them.

Additionally, due to the effectiveness of the educational videos and games, students suggested that ICT must be introduced in teaching of Social Studies but it must be made a permanent part of all other subjects e.g. Science and Math etc. as well. Hence, maintaining balance and equilibrium in all subjects.

Activity Theory model was applied as theoretical and an analytical framework for this study. Activity Theory helped to perform any human activity within a system. For the thematic analysis of qualitative data, activity theory helped in generation of themes from the data. Importantly, it helped to understand in detail different aspects of entire activity i.e. teaching social studies with educational videos and games in schools.

\section{Contribution}

Teaching through educational videos and games were previously used in mathematics and science subjects only, but Social Studies subject was among one of the ignored subjects in this regard. Social Studies also hold importance like all other subjects. In Pakistani perspective, this experimental study was conducted for the first time by utilizing educational videos and games for the teaching and learning of different concepts of Social Studies subject, in best of my knowledge.

\section{Conclusion}

In the view of $21^{\text {st }}$ century teaching skills, knowledge and proper integration of Information and Communication Technologies (ICTs) into teaching is essential and mandatory for all teachers and learners. Teachers can use educational technology in the classroom to make their teaching more interactive and meaningful. Educational videos and games as a tool proved beneficial for teaching and learning. Educational videos and games were not only helpful for teachers, nevertheless, these were very useful for learners at secondary school. They learned effectively, like active learners, as compared to traditional lecture method. Therefore, teachers need to plan different activities in their teaching, where they can utilise educational videos and games to facilitate student's learning. More importantly, teacher can find many educational videos and games, freely available on internet. It appeared from the findings of this research that students' were able to learn better the abstract concepts of social studies subject, through educational videos and games in the classroom. It enabled students to get information by watching their subject relevant 
videos and games independently. There is no single solution for good teaching and learning; educational videos and games can be used as an effective and essential tool for learning. The $21^{\text {st }}$ Century demands effective teaching in which educators try to train learners as a global citizen with equality, to collaborate with each other. 


\section{References}

Acikalin, M., \& Erdinç, D. U. R. U. (2005). The use of computer technologies in the social studies classroom. TOJET: The Turkish Online Journal of Educational Technology, 4(2), 1-89.

Adomi, Esharenana E. \& Anie, Silvester O. (2006) An Assessment of Computer Literacy Skills of Professionals in Nigerian University Libraries. Library Hi Tech News, 23 (2), pp.10-14

Bloom, B. S. (1956). "Taxonomy of Educational Objectives, Handbook I: The Cognitive Domain." New York: David McKay Co Inc.

Cohen, J. (1988). Statistical Power Analysis for the Behavioural Sciences. 2nd ed. Routledge, Oxon.

Cohen, J. (1992). A power primer. Psychological Bulletin, 112(1), 155-159.

Cohen, L., Manion, L. \& Morrison, K. (2011). Research Methods in Education. Routledge, Taylor \& Francis Group. London and New York.

Collis, B. (1999). Designing for differences: Cultural issues in the design of WWW based course support sites. British journal of educational technology, 30(3), 201-215.

Collis, B., \& Wende, M. (2002). Models of technology and change in higher education: An international comparative survey on the current and future use of ICT in higher education. Enschede: CHEPS/Toegepaste Onderwijskunde.

Engeström, Y (1987). 'Learning By Expanding: An Activity Theoretical Approach to Developmental Research', Orienta-Konsultit, Helsinki.

Field, A. (2009). Discovering Statistics using SPSS. 3rd ed. London; Thousand Oaks.

Gaudence, O., Too, J. K., \& Nabwire, V. K. (2013) Enhancing Learning of Geography: A Focus on Video Use. International J. Soc. Sci. \& Education, 4(1), 277-288.

Gaudence, O., Too, J. K., \& Nabwire, V. K. (2013) Enhancing Learning of Geography: A Focus on Video Use. International J. Soc. Sci. \& Education, 4(1), 277-288.

Goktas, Y., Yildirim, Z., \& Yildirim, S.(2009) Investigation of K-12 Teachers' ICT competencies and contributing factors in acquiring these competencies. The New Educational Review, 17(1), 276-296 
Greenberg, A. D., \& Zanetis, J. (2012). The impact of broadcast and streaming video in education. Cisco: Wainhouse Research.

Gulbahar, Y., \& Guven, I. (2008). A Survey on ICT Usage and the Perceptions of Social Studies Teachers in Turkey. Educational Technology \& Society, 11(3), 37-51.

Hsu, C.-K., Hwang, G.-J., Chang, Y.-T., \& Chang, C.-K. (2013). Effects of Video Caption Modes on English Listening Comprehension and Vocabulary Acquisition Using Handheld Devices. Educational Technology \& Society, 16 (1), 403-414.

Jaipal, K., \& Figg, C. (2009). Using video games in science instruction: Pedagogical, social, and concept-related aspects. Canadian Journal of Science, Mathematics and Technology Education, 9(2), 117-134.

Juang, Y. R., Liu, T. C., \& Chan, T. W. (2008). Computer-Supported Teacher Development of Pedagogical Content Knowledge through Developing School-Based Curriculum. Educational Technology \& Society, 11(2), 149-170.

Kili, K. (2005). Digital game-based learning: Towards an experiential gaming model. The Internet and Higher Education, 8(1), 13-24.

Le Fevre, D. M. (2004). Designing for teacher learning: Video-based curriculum design. Advances in Research on Teaching, 10, 235-258.

Lim, C. P. (2001). Object of the activity systems as a major barrier to the creative use of ICT in schools. Australian Journal of Educational Technology 17 (3): 295-312.

Lim, C. P. and D. Hang (2003). An activity theory approach to research of ICT integration in Singapore schools. Computers \& Education 41(1): 49-63.

Maguth, B. M., List, J. S., \& Wunderle, M. (2015). Teaching Social Studies with Video Games. The Social Studies, 106(1), 32-36.

Mwanza, D. and Y. Engeström (2005). Managing content in e-learning environments. British Journal of Educational Technology 36(3): 453-463.

Ni, L. B., (2012). ICT Use In Teaching and Learning of History. International Journal of Computer Networks and Wireless Communications (IJCNWC), 2(4), 428-433. 
Prensky ,M. (2001). Digital game-based learning. New York: McGraw-Hill.

Prensky, M. (2006). "Don't interrupt me mom, I'm learning." St. Paul, MN: Paragon House.

Safder, A. (2013). Effectiveness of Information and Communication Technology (ICT) in Mathematics at secondary level. (Doctoral dissertation). Retrieved on $10^{\text {th }}$ Oct, 2015 from prr.hec.gov.pk/Thesis/1838S.pdf.

Sedaghat, A. M., Mintz, S. M., \& Wright, G. M. (2011). Using VideoBased Instruction to Integrate Ethics into the Curriculum. American Journal of Business Education, 4(9), 57-76.

Sheffield, C.J. (1996). An examination of self-reported computer literacy skills of pre-service Teachers Action in teacher Education 17(4), 4552.

Tolmie, A. and J. Boyle (2000). "Factors influencing the success of computer mediated communication (CMC) environments in university teaching: a review and case study." Computers \& Education 34(2): 119-140.

Vygotsky, L. S. (1978). Mind in Society: The Development of Higher Psychological Processes. Cambridge MA, Harvard University Press.

Walls, R. (2012). Using computer games to teach social studies. Studies (Master's thesis, Uppsala University Department of Education, 2012). Sweden.

Wheelar, S. (2001) ICT and the Changing Role of the Teacher. Journal of Educational Media, 26(1), 7-18

Yang, J. C., Huang, Y. T., Tsai, C. C., Chung, C. I., \& Wu, Y. C. (2009). An Automatic Multimedia Content Summarization System for Video Recommendation. Educational Technology \& Society, 12(1), 49-61.

Yocam, K., F. Wilmore, et al. (1994). Situated teacher development: ACOT's two-year pilot project, Apple Classrooms of Tomorrow Rep

\section{Citation of this Article:}

Khurshid, F., \& Bibi, M. (2020). Effectiveness of educational videos and games for the concepts clarity and understanding of social studies subject: An intervention study. Pakistan Journal of Education, 37 (2), 61-78. 